\title{
Diversity of soil mite communities (Acari) within habitats seasonally flooded by the Vistula River (Ostromecko, Poland)
}

\author{
SŁAWOMIR KACZMAREK ${ }^{1}$, TOMASZ MARQUARDT ${ }^{1}$ \\ KATARZYNA FALEŃCZYK-KOZIRÓG ${ }^{1}$ and KATARZYNA MARCYSIAK ${ }^{2}$ \\ Kazimierz Wielki University, Institute of Environmental Biology \\ ${ }^{1}$ Department of Zoology, ${ }^{2}$ Department of Botany \\ Ossolińskich 12, 85-094 Bydgoszcz, Poland \\ Corresponding author: Sławomir Kaczmarek, slawkacz@ukw.edu.pl
}

(Received on 2 June 2011; Accepted on 21 January 2012)

\begin{abstract}
The research was carried out in three types of habitats located in the seasonally flooded area of the Vistula River within Wielka Kępa Ostromecka Reserve: Salicetum albo-fragilis, Fraxino-Alnetum and Populetum albae. In the soil of Salicetum albo-fragilis Veigaia nemorensis and Trichouropoda ovalis were abundant, while Fraxino-Alnetum was dominated by Rhodacarellus silesiacus, and Populetum albae was overwhelmed by Rhodacarellus silesiacus and Dinychus inermis. Only between the Mesostigmata communities populating Fraxino-Alnetum and Populetum albae there were no statistically significant differences recorded in the distribution of abundance. The most similar, from the qualitative, quantitative and qualitative-quantitative point of view were Mesostigmata communities inhabiting Fraxino-Alnetum and Populetum albae. The numerous occurrence of Rhodacarellus silesiacus population in the soil of Fraxino-Alnetum and Populetum albae is most probably the result of succession changes within those habitats, and the species itself can be seen as an indicator of those habitats undergoing the process of a riparian forest transforming into an oak-hornbeam forest vegetation type.
\end{abstract}

Keywords: Mesostigmata, bioindicators of habitat transformation, seasonally flooded areas

\section{INTRODUCTION}

Up until now, acarological research attempting to characterize synecological mite groups occurring in particular environmental conditions has only been carried out regarding the Cryptostigmata. Their occurrence depending on the combination of ecological factors was studied by, among others, STRENZKe (1952), RAJSKi (1961, 1967, 1968, 1970), Wood (1967) and Niedbata $(1969,1976)$. Apart from the aforementioned authors highlighting particular synecological groups called synusia (e.g. Hydrozetes lemnae synusium of underwater mosses and eutrophic reservoir algae), RAJSKI (1961) also studied the succession of Cryptostigmata communities taking place simultaneously, although with some delay, with the succession of vegetative 
communities. Information concerning the synusia of the Mesostigmata only appear in Wood (1967), where in the synusium inhabiting the litter under the Sesleria he also lists, except the Oppiella obsoleta (Cryptostigmata), the Rhodacarus roseus (Mesostigmata: Rhodacaridae). Among the Gamasina we know species preferring mainly high humidity level habitats, such as e.g. Platyseius italicus, Veigaia transisalae or species of the Cheiroseius genus (e.g. BuKowsKi et al. 2002; KACZMAREK \& MARQUARDT 2004, 2007a, b), yet there has been hitherto no attempt to generalize the system of habitat valorization by mite communities of that group.

The following paper aims at defining the diversity of communities inhabiting various types of seasonally flooded riparian forests of the Vistula River area as well as attempting to valorize the habitats using Mesostigmata communities found there.

\section{MATERIAL AND METHODS}

The study was carried out in three types of riparian forests: willow Salicetum albo-fragilis (Saf), alder and ash Fraxino-Alnetum (FA) and aspen Populetum albae (Pa) within Wielka Kępa Ostromecka Reserve (53.14N, 18.18E).

Salicetum albo-fragilis developed in a topographic depression and, dominated by Urtica dioica, was characterized by the occurrence of riverside shrubs including Humulus lupulus and Calystegia sepium.

The remaining studied riparian habitats were located slightly higher and alluded to habitats undergoing the process of a riparian forest transforming into an oak-hornbeam forest vegetation type. Fraxino-Alnetum was dominated by Ulmus minor and its rich shrubs layer was mainly composed of Padus avium and Cornus sanguinea. The relatively weakly developed undergrowth contained oak-hornbeam forests species, including Ficaria verna, and Aegopodium podagraria was the most numerous. Apart from nitrophilous shrub species of forest edges and dogwood seedlings there were recorded no other accompanying species. As for Populetum albae, it was floristically richer. Both oak-hornbeam forests species and nitrophilous shrubs of forest edges were numerous there. Characteristic species - Salix alba and Populus nigra - were represented by single old trees and other tree species were not recorded. That community basically lost its riparian character and its species composition was similar to that of an oak-hornbeam forests.

Soil samples form each habitat were taken from three layers of soil profile (upper: $2 \mathrm{~cm}$, middle: $5 \mathrm{~cm}$ and lower: $5 \mathrm{~cm}$ ). In each habitat from each layer 40 samples, each $50 \mathrm{~cm}^{3}$ (cylindrical cores with a diameter of $4 \mathrm{~cm}$ and a length of $4 \mathrm{~cm}$ ), were taken in spring and autumn of 2006. There were 240 soil samples altogether assembled from every habitat, each $50 \mathrm{~cm}^{3}$ and up to $12 \mathrm{~cm}$ deep (120 in each of the respective research periods). Overall, 720 soil samples were analyzed, from which after a six-day extraction in Tullgren funnels 9099 mites were extracted, including 7960 of the Cryptostigmata and 1005 of the Mesostigmata. All the mites were identified to the order, and the Mesostigmata to the species with respect to all their developmental forms (Micherdziński 1969; BŁaszak 1974; Bregetova 1977; Hyatt 1980; KarG 1993; BŁoszyk 1999; MašÁn 2001, 2003; MašÁn \& FenĎa 2004; Kalúz \& FenĎA 2005; GWIAZDOWICZ 2007). 
Zoocenological analysis was performed using the indices of abundance (A in ind. $\left./ \mathrm{m}^{2}\right)$, dominance ( $\mathrm{D}$ in \%), constancy $\left(\mathrm{C}\right.$ in \%), species diversity $\left(\mathrm{H}^{\prime}\right)$ and evenness (J') of the communities. Abundance per square meter was calculated with respect to sampled soil layer thickness and sampled cores dimensions. The analysis results of qualitative similarity (Sorensen index), quantitative similarity (Morisita index) and qualitative-quantitative similarity (percent similarity based on Bray-Curtis index) were presented as dendrograms prepared with UPGMA method using the MVSP 3.20 (Kovach Computing Services 2010). Statistical significance of differences in abundance distribution in samples of Acari, Mesostigmata and Cryptostigmata between the studied habitats was assessed using Kruskal-Wallis and Bonferroni tests (WINER et al. 1991).

\section{RESULTS}

The lowest abundance levels of the Acari, Cryptostigmata and Mesostigmata were recorded in the soil of Fraxino-Alnetum (5 360 ind. $/ \mathrm{m}^{2}, 3410$ ind. $/ \mathrm{m}^{2}$ and 1750 ind. $/ \mathrm{m}^{2}$ respectively), while their most numerous populations were found in the soil of Salicetum albo-fragilis (40 640 ind. $/ \mathrm{m}^{2}, 36590 \mathrm{ind} . / \mathrm{m}^{2}$ and $3630 \mathrm{ind} . / \mathrm{m}^{2}$ respectively) (Table 1). Statistically significant differences in abundance distribution were not recorded only between the Mesostigmata communities inhabiting FraxinoAlnetum and Populetum albae (Fig. 1), whereas in all other cases the established differences were statistically highly significant $(P<0.01)$.

Overall, 17 Mesostigmata families were recorded in the studied riparian forests. In the soil of Salicetum albo-fragilis families of Veigaiidae (28.4\%) and Trematuridae $(18.3 \%)$ were dominant, whereas in Fraxino-Alnetum and Populetum albae representatives of the Parasitidae (27.4\% and $23.7 \%$ respectively) and Rhodacaridae (23.1\% and $27.4 \%$ respectively) were numerous.

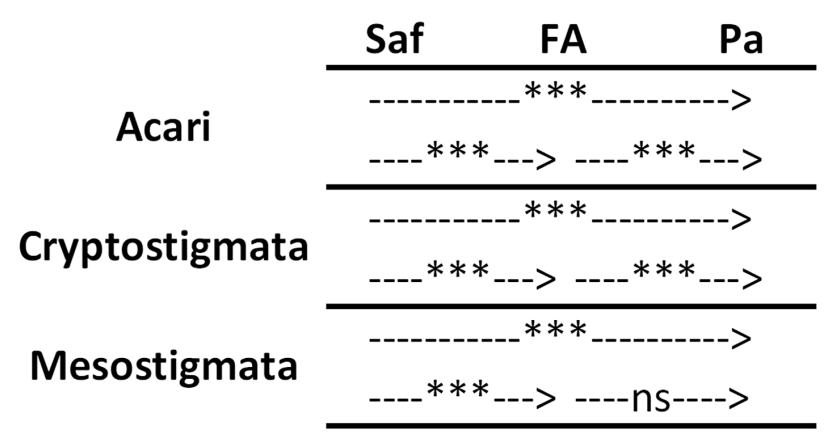

Fig. 1. Statistical analysis results on the significance of differences in the abundance distribution of the Acari, Cryptostigmata and Mesostigmata between the studied habitats of Wielka Kępa Ostromecka Reserve (Bonferroni test: ${ }^{* * *} P<0.01$; ns - statistically not significant). Saf - Salicetum albo-fragilis, FA - Fraxino-Alnetum, $\mathrm{Pa}$ - Populetum albae 
Table 1. Abundance indices (A in ind.$/ \mathrm{m}^{2}$ ) of Acari, Cryptostigmata and Mesostigmata communities. Dominance (D in \%) and constancy (C in \%) of selected Mesostigmata species (SD computed for each habitat from 240 samples). The number of species (S) as well as the indices of species diversity (H') and evenness (J') of Mesostigmata communities within the studied habitats of Wielka Kępa Ostromecka Reserve. The list of remaining species (including the habitat) is included below the table. Saf-Salicetum albo-fragilis, FA - Fraxino-Alnetum, $\mathrm{Pa}$ - Populetum albae

\begin{tabular}{ccccccc}
\hline & \multicolumn{2}{c}{ Saf } & \multicolumn{2}{c}{ FA } & \multicolumn{2}{c}{ Pa } \\
\hline Acari - A & $40640 \pm 674.2$ & $5360 \pm 56.2$ & $16290 \pm 174.6$ \\
\hline Cryptostigmata - A & $36590 \pm 609.4$ & $3410 \pm 49.2$ & $13590 \pm 147.3$ \\
\hline Mesostigmata - A & \multicolumn{2}{c}{$3630 \pm 65.4$} & $1750 \pm 27.3$ & $2230 \pm 31.3$ \\
\hline Mesostigmata species & D & C & D & C & D & C \\
\hline Dinychus inermis (C. L. Koch, 1841) & & & & & 13.17 & 48.75 \\
Rhodacarellus silesiacus Willmann, 1936 & 6.18 & 21.25 & 20.31 & 27.50 & 26.67 & 43.75 \\
Trichouropoda ovalis (C. L. Koch, 1839) & 18.26 & 60.00 & 0.28 & 1.25 & 1.67 & 6.25 \\
Veigaia nemorensis (C. L. Koch, 1839) & 28.48 & 56.25 & 3.98 & 8.75 & 2.68 & 6.25 \\
\hline S & \multicolumn{2}{c}{36} & & 33 & & 26 \\
H' & \multicolumn{2}{c}{2.542} & 2.763 & & 2.568 \\
J' & 0.709 & 0.790 & & 0.788 \\
\hline
\end{tabular}

Ascidae: Asca bicornis (Canestrini et Fanzago, 1887) - Saf; Gamasellodes bicolor (Berlese, 1918) - Saf, FA, Pa; Celaenopsidae: Celaenopsis badius C.L.Koch, 1839 - Saf; Digamasellidae: Dendrolaelaps septentrionalis (Sellnick, 1958) - Saf, FA, Pa; Eviphididae: Eviphis ostrinus (C.L.Koch, 1836) - Saf, FA, Pa; Iphidosoma sp. Berlese, 1892 - FA, Pa; Laelapidae: Hypoaspis aculeifer (Canestrini, 1883) - Saf, FA, Pa; Macrochelidae: Geholaspis mandibularis (Berlese, 1904) - Saf, FA; Macrocheles montanus (Willmann, 1951) - Saf, Fa, Pa; Macrocheles sp. Latreille, 1829 - FA; Pachylaelapidae: Pachylaelaps dubius Hirschmann et Krauss, 1965 - Saf; Pachylaelaps furcifer Oudemans, 1903 - Saf, FA, Pa; Pachylaelaps hispani Berlese, 1903 - FA; Pachylaelaps longisetis Halbert, 1915 - Saf; Pachylaelaps spectabilis Berlese, 1910 - Saf; Pachyseius humeralis Berlese, 1910 - Saf; Pachyseius sp. Berlese, 1910 - Saf; Parasitidae: Eugamasus crassitarsis (Halbert, 1923) - FA; Holoparasitus excipuliger (Berlese, 1903) - Saf, FA, Pa; Holoparasitus sp. Oudemans, 1936 - Saf; Leptogamasus parvulus (Berlese, 1903) - Pa; Paragamasus holzmannae (Micherdziński, 1969) - Saf; Paragamasus misellus (Berlese, 1903) - Saf; Paragamasus runcatellus (Berlese, 1903) - Saf, FA, Pa; Paragamasus runciger (Berlese, 1903) - FA; Parasitus lunulatus (Müller 1859) - FA; Pergamasus brevicornis Berlese, 1903 - Saf, FA, Pa; Pergamasus crassipes (Linne, 1758) - Saf, FA,Pa; Pergamasus quisquiliarum (Canestrini, 1882) - FA; Pergamasus viator Halaškova, 1959 - Saf, FA, Pa; Pergamasus sp. Berlese, 1903 - Saf, FA, Pa; Phytoseiidae: Amblyseius obtusus (C.L.Koch, 1839) - FA, Pa; Amblyseius sp. Berlese, 1904 - Saf, Pa; Phytoseius sp. Ribaga, 1904 - Saf; Polyaspidae: Polyaspinus schweizeri (Hutu, 1976) - FA; Rhodacaridae: Minirhodacarellus minimus (Karg, 1961) - Pa; Rhodacarus coronatus Berlese, 1921 - FA, Pa; Rhodacarus mandibularis Berlese, 1921 - Saf, FA; Trachytidae: Trachytes aegrota (C.L.Koch, 1841) - Saf; Urodinychidae: Uroobovella cf pyriformis (Berlese,1920) - FA; Uroobovella sp. Berlese, 1905 - Pa; Urodiaspis pannonica Willmann, 1951 - Saf; Urodiaspis tecta (Kramer. 1876) - Saf, FA, Pa; Uropodidae: Discourella modesta (Leonardi, 1899) - Saf, FA, Pa; Uropoda minima Kramer, 1882 - Saf, FA; Uropoda sp. Latreille, 1806 - Saf; Zerconidae: Prozercon traegardhi (Halbert, 1923) - FA; Zercon triangularis C.L.Koch, 1836 - Saf, Pa. 
Altogether, 53 Mesostigmata species were recorded within the studied area and their number fluctuated between 26 in Populetum albae and 36 in Salicetum albofragilis.

Dominant species in Salicetum albo-fragilis was Veigaia nemorensis $(\mathrm{D}=28.48 \%$, $\mathrm{C}=56.25 \%)$ and Trichouropoda ovalis $(\mathrm{D}=18.26 \%, \mathrm{C}=60.00 \%)$. In the soil of FraxinoAlnetum and Populetum albae populations of Rhodacarellus silesiacus were numerous $(\mathrm{D}=20.31 \%, \mathrm{C}=27.50 \%$ and $\mathrm{D}=26.67 \%, \mathrm{C}=43.75 \%$ respectively), and in Populetum albae Dinychus inermis was a co-dominant species $(\mathrm{D}=13.17 \%, \mathrm{C}=48.75 \%)$.

The lowest levels of diversity H' and evenness J' were accounted for Mesostigmata communities in Salicetum albo-fragilis (2.542 and 0.709 respectively), whereas their highest values (2.763 and 0.790 respectively) were recorded for Mesostigmata communities inhabiting Fraxino-Alnetum.

The highest qualitative, quantitative and percent similarities were recorded between Mesostigmata communities inhabiting Fraxino-Alnetum and Populetum albae (Fig. 2).

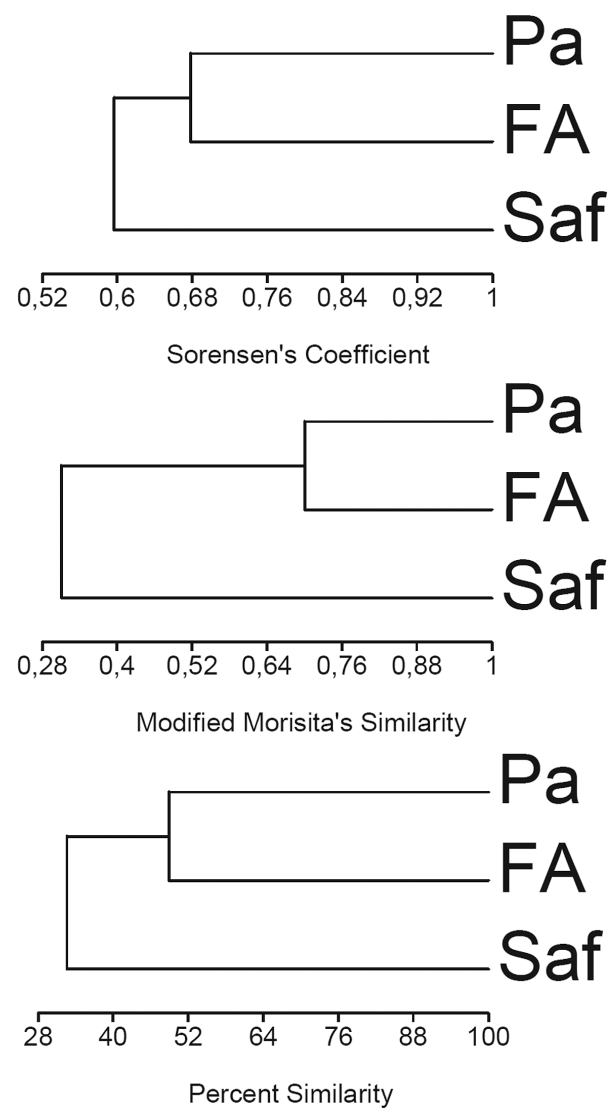

Fig. 2. Dendrograms of qualitative (Sorensen), quantitative (Morisita) and qualitative-quantitative similarity (Percent Similarity) of Mesostigmata communities populating the habitats of Wielka Kępa Ostromecka Reserve. Saf - Salicetum albo-fragilis, FA - Fraxino-Alnetum, $\mathrm{Pa}$ - Populetum albae 


\section{DISCUSSION}

Assessing the influence of habitat conditions on the development of mite communities has been up until now analyzed in detail based on Cryptostigmata populations only (RAJSKI 1961, 1967, 1968, 1970; Wood 1967; Niedbata 1969, 1976). Synecological groups that were marked as a result of that analysis occur in habitats with particular combination of environmental factors such as e.g. humidity, $\mathrm{pH}$, salinity, vegetation type etc. Certainly, apart from basic factors such as e.g. humidity, the type of vegetation supplying the mites with nutrition in the form of dead organic matter with appropriate qualities (depending on the vegetation community) is essential in the development of Cryptostigmata communities. Such direct relationship between the saprophagous Cryptostigmata with dead organic waste made it possible to connect particular vegetation communities with Cryptostigmata communities characterized by specific (typical for the community) species structures called synusia (STRENZKE 1952; RAJSKI 1961). Based on habitats of alder swamp forests and probably riparian forests the Nanhermannia comitalis Berlese synusium was described and the conditions occurring in the soil of sweet meadows shape the Ceratozetes mediocris synusium appearing there (RAJSKI 1961).

As a consequence of their position in the trophic structure of the ecosystem, the Mesostigmata are linked to the vegetation community type only indirectly. Predatory Gamasina can only indirectly react to the vegetation type by feeding on e.g. juvenile forms of the Cryptostigmata living there, whereas the saprophagous Uropodina are possibly more connected to the vegetation type. So far, however, the possibility of defining Mesostigmata synusia has not been researched.

The populations of Veigaia nemorensis and Trichouropoda ovalis occurring in Salicetum albo-fragilis cannot be treated as typical for that habitat due to their eurytopism (e.g. BŁoszyK 1999; MAšÁn 2001; KACZMAREK et al. 2006). As for Rhodacarellus silesiacus that is numerous in the soil of Fraxino-Alnetum and Populetum albae, up until now it has also been listed in other habitats, including the postindustrial wasteland, as a pioneer species (KARG \& Freier 1995; MAdej 2004). Only Dinychus inermis that is co-dominant in Populetum albae is a species bearing a narrow ecological tolerance range - it is hygrophilous but occurring in different types of vegetation communities (BŁosZYK 1999; MAŠÁN 2001).

The Fraxino-Alnetum complex is characterized by a considerable habitat changeability, mainly depending on humidity, developing (at higher areas) forms similar to oak-hornbeam forests, often creating a transitory strip between alder swamp forests and typical oak-hornbeam forests. The occurrence of Populetum albae, similarly to Salicetum albo-fragilis, is connected with riverside areas, yet the former community develops at slightly higher plains (Matuszkiewicz 2002). Mites of the Rhodacaridae family, whose occurrence in coniferous forest soils is limited to the deeper situated mineral layers (e.g. KACZMAREK et al. 2006), can occur numerously in the upper layers of the soil profile in soils with mull decay (e.g. in Tilio-Carpinetum) (FALEŃCZYKKozIRóG personal information). Within the studied Salicetum albo-fragilis soil water level was high enough to limit the occurrence of the Rhodacaride, which was similar 
to the soils of wet and moist Pine forests (KACZMAREK et al. 2006). The Rhodacaridae (primarily $R$. silesiacus) occurred numerously in the soils of Fraxino-Alnetum and Populetum albae due to their slightly higher locations.

\section{CONCLUSIONS}

Mesostigmata communities that would be typical for the studied riparian forests exclusively were not recorded, although the most similar communities inhabited Fraxino-Alnetum and Populetum albae that were undergoing the process of a riparian forest transforming into an oak-hornbeam forest vegetation type. In case of that group of mites, the lack of a clear relationship between the type of phytocenosis and zoocenosis is probably related to their activity and ability to migrate. The numerous occurrence of Rhodacarellus silesiacus in the soil of Fraxino-Alnetum and Populetum albae can be a good indicator of not the type of habitat but the processes that habitat undergoes. In our assessment, the occurrence of numerous $R$. silesiacus populations signifies the gradual processes of Fraxino-Alnetum and Populetum albae transforming into an oak-hornbeam forest vegetation type and as such it can be used to assess those processes taking place in riparian forests (irrespective of them being natural or anthropogenically induced).

\section{REFERENCES}

BŁaszak C. 1974. Zeronidae (Acari, Mesostigmata) Polski [Zerconidae (Acari, Mesostigmata) of Poland]. Monogr. Faun. Pol., vol. 3, PWN, Warszawa - Kraków (in Polish).

BŁoszYK J. 1999. Geograficzne and ekologiczne zróżnicowanie zgrupowań roztoczy z kohorty Uropodina (Acari: Mesostigmata) w Polsce. I. Uropodina lasów grądowych (Carpinion betuli) [Geographical and ecological variability of mites of the cohort Uropodina (Acari: Mesostigmata) in Poland. I. Uropodine mites of oak-hornbeam forests (Carpinion betuli)]. Kontekst, Poznań (in Polish).

Bregetova I. G. 1977. Opredelitel obitayushchikh w pochve kleshchei [Identification key to soil inhabiting mites of Mesostigmata]. Nauka, Leningrad (in Russian).

Bukowski G., Seniczak S., Kaczmarek S. 2002. The mites (Acari) of clusters of moor grass and sedge in the flooded coast of the Małe Gacno lake in the National Park Bory Tucholskie. In: Postępy polskiej akarologii (Ignatowicz S., Ed.), pp. 163-168, Wyd. SGGW, Warszawa.

GwiazDowicz D. J. 2007. Ascid mites (Acari, Mesostigmata) from selected forest ecosystems and microhabitats in Poland. Wyd. AR, Poznań.

Hyatт K. H. 1980. Mites of the subfamily Parasitinae (Mesostigmata: Parasitidae) in the British Isles. Bull. Brit. Mus. (Nat. Hist.), Zool. 38: 237-378.

Kaczmarek S., Marquardt T. 2004. Contribution to the biodiversity of gamasid soil mites (Acari) in the „Bagno Stawek” reserve within a planned biosphere reserve (Tuchola Forest, Poland). In: Phytophaga XIV. Proceedings of the $5^{\text {th }}$ Symposium of the European Association of Acarologists. Acarine Biodiversity in the Natural and Human Sphere (Weigmann G., Alberti G., Wohltmann A., Ragusa S., Eds), June 26-30, 2004, Berlin, Germany, pp. 237-242, Tipolitografia Luxograph, Palermo, Italy. 
Kaczmarek S., Marquardt T. 2007a. Soil Gamasida (Acari) in various pine forests and in ecotones between them in the 'Bagno Stawek' Reserve, Tuchola Forest (N Poland). In: Contributions to Soil Zoology in Central Europe II. (Tajovský K., Schlaghamerský J., Pižl V., Eds), pp. 83-86, ISB, ASCR, České Budějovice.

Kaczmarek S., Marquardt T. 2007b. Gamasida communities (Acari) in the Caricetum lasiocarpae fen of the Bagno Stawek Reserve, Tuchola Forest (N Poland). In: Contributions to Soil Zoology in Central Europe II. (Tajovský K., Schlaghamerský J., Pižl V., Eds), pp. 79-82. ISB, ASCR, České Budějovice.

Kaczmarek S., Marquardt T., Marcysiak K. 2006. Preliminary research on communities of soil gamasid mites (Acari) in three different pine forests in the „Bagno Stawek” reserve (Tuchola Forest, N Poland). In: Postępy polskiej akarologii (GabrYś G., Ignatowicz S., Eds), pp. 137 148, Wyd. SGGW, Warszawa.

Kalúz S., FenĎa P. 2005. Mites (Acari, Mesostigmata) of the family Ascidae of Slovakia. Institute of Zoology, Slovak Ac. Sci., Bratislava.

Karg W. 1993. Acari (Acarina), Milben Parasitiformes (Anactinochaeta) Cohors Gamasina Leach. Raubmilben [Predatory mites, Acari (Acarina), Parasitiformes (Anactinochaeta) Cohors Gamasina Leach]. Die Tierwelt Deutschlands 59: 1-523 (in German).

Karg W., Freier B. 1995. Parasitiforme Raubmilben als Indikatoren für den ökologischen Zustand von Ökosystemen [Predatory Parasitiformes mites as indicators of the ecological status of ecosystems]. Biol. Bund. Land. Forst., Berlin - Dahlem, 308: 1-96 (in German).

Madej G. 2004. Rozwój zgrupowań roztoczy Mesostigmata (Arachnida, Acari) na nieużytkach poprzemysłowych [Development of communities of mesostigmatid mites (Arachnida, Acari) in areas of postindustrial wastelands]. Wyd. UŚ, Katowice (in Polish).

MAš́́n P. 2001. Mites of the cohort Uropodina (Acarina, Mesostigmata) in Slovakia. Annot. Zool. Bot. 223: 1-320 (in Slovak).

MAŠ́́n P. 2003. Macrochelid mites of Slovakia (Acari, Mesostigmata, Macrochelidae). Institute of Zoology, Slovak Ac. Sci., Bratislava.

MAš́n P., FENĎA P. 2004. Zerconid mites of Slovakia (Acari, Mesostigmata, Zerconidae). Institute of Zoology, Slovak Ac. Sci., Bratislava.

Matuszkiewicz J. M. 2002. Zespoły leśne Polski [Forest associations in Poland]. PWN, Warszawa (in Polish).

MicherdZiński W. 1969. Die familie Parasitidae Oudemans 1901 (Acarina, Mesostigmata) [Family Parasitidae Oudemans 1901 (Acarina, Mesostigmata)]. PWN, Warszawa (in German).

Niedbąa W. 1969. Fauna mechowców (Acari, Oribatei) nadrzewnych okolic Poznania [Fauna of arboreal moss mites (Acari, Oribatei) in the Poznań environs]. Pol. Pis. Ent. 39: 83-94 (in Polish).

Niedbata W. 1976. Brachychthoniidae Polski (Acari, Oribatei). Studium ekologiczno-faunistyczne [Brachychthoniidae of Poland (Acari, Oribatei). Ecological-faunistical study]. Monogr. Faun. Pol., vol. 6, PWN, Warszawa - Kraków (in Polish).

RAJSKI A. 1961. Studium ekologiczno-faunistyczne nad mechowcami (Acari, Oribatei) w kilku zespołach roślinnych [Faunistic-ecological investigations on moss mites (Acari, Oribatei) in several plant associations]. Pr. Kom. Mat.-Przyr. PTPN, 25: 1-161 (in Polish).

RAJSKI A. 1967. Autecological-Zoogeographical Analysis of Moss Mites (Acari, Oribatei) on the basis of Fauna in the Poznań Environs. Part I. Pol. Pis. Ent. 37: 69-166.

RAJSKI A. 1968. Autecological-Zoogeographical Analysis of Moss Mites (Acari, Oribatei) on the basis of Fauna in the Poznań Environs. Part II. Fragm. Faun. 14: 277-405.

RAJSKI A. 1970. Autecological-Zoogeographical Analysis of Moss Mites (Acari, Oribatei) on the basis of Fauna in the Poznań Environs. Part III. Acta Zool. Cracov. 15: 161-257.

StrenZKe K. 1952. Untersuchungen über die Tiergemeinschaften des Bodens: Die Oribatiden und ihre Synusien in der Böden Norddeutschlands [Studies on the soil animal communities: The 
oribatid mites and their synusia in the soils of northern Germany]. Zoologica 104: 1-172 (in German).

Winer B. J., Brown D. R., Michels K. M. 1991. Statistical principles in experimental design. (3rd ed.) McGraw-Hill, Boston.

Wood T. G. 1967. Acari and Collembola of moorland soils from Yorkshire, England. III. The microarthropod communities. Oikos 18: 277-292. 